\title{
MISSED MALIGNANCY IN MIXED BILATERAL BENIGN BREAST LESIONS- A CLINICAL STUDY
}

\author{
Sankararaman Balasubramanian'1, Bharathidasan Rajamanickam², Ambujam Govindasamy33, Raj Prakash Chandramohan ${ }^{4}$
}

${ }_{1}^{1}$ Associate Professor, Department of General Surgery, Private Clinic and Vinayaka Missions Medical College, Karaikal. ${ }^{2}$ Associate Professor, Department of General Surgery, Private Clinic and Vinayaka Missions Medical College, Karaikal. 3 Professor and HOD, Department of General Surgery, Private Clinic and Vinayaka Missions Medical College, Karaikal. ${ }^{4}$ Postgraduate Student, Department of General Surgery, Private Clinic and Vinayaka Missions Medical College, Karaikal.

\section{ABSTRACT}

\section{BACKGROUND}

Though breast diseases even in benign status poses considerable anxiety and fear to the suffering woman and to her blood relatives, this leads to extensive investigative modalities in benign breast diseases including MRI and wire localisation of the impalpable lesion and biopsy to prove beyond doubt that it is not malignant. This paper is to enlighten the critical situation to which we were pushed in our analysis of 4 cases of bilateral benign cystic breast diseases who were diagnosed to have malignancy in one of the bre asts during periodic followup, while they were on conservative treatment.

The interesting facts like- 1 . Malignancy after wide excision for cystic lesions; 2 . Incidence of malignancy in the family, 3 of the 4 patients; 3. Association of HER-2/neu oncogene positivity status in all the patients; 4 . Demand and decision to do bilateral prophylactic mastectomy in patients even though the breast lesion proved to be benign.

\section{MATERIALS AND METHODS}

The study was conducted in Vinayaka Missions Medical College, Karaikal and Private Clinic in Thanjavur. A series of 320 cases of benign breast disease of varying ages from 20 to 60 years were studied for a period of 2 years. Diagnosis was made by means of histopathological examination and sonomammogram. Followup was done for a minimum period of 1 year.

\section{RESULTS}

320 cases of bilateral benign breast disease were studied, out of which 4 cases were found to be malignant during followup. The 4 cases were studied briefly and the results were as follows.

- 316 cases were found to be benign even after followup for a minimum period of 1 year.

- 4 cases were found to be malignant during followup.

- 3 out of 4 patients had family history of breast malignancy.

- 3 of 4 patients had ER +ve

- $\quad$ PR +ve

- $\quad$ HER-2/neu +ve

- 1- nulliparous unmarried.

- $\quad$ All four above the age of 40 years.

- High risk patients for developing malignancy.

\section{CONCLUSION}

High risk population must be screened routinely. The risk of malignancy is very high following benign breast disease. Other factors such as age, nature of discharge, parity and family history were taken into account and treatment was tailored according to the diagnosis.

\section{KEYWORDS}

Malignancy in Benign Breast Lesion, Bilateral Breast Lesion, Treatment.

HOW TO CITE THIS ARTICLE: Balasubramanian S, Rajamanickam B, Govindasamy A, et al. Missed malignancy in mixed bilateral benign breast lesions- a clinical study. J. Evolution Med. Dent. Sci. 2017;6(37):2994-2999, DOI: 10.14260/Jemds/2017/646

\section{BACKGROUND}

- The breast is a modified sweat gland composed of both epithelial and connective tissue elements. Therefore, neoplasms arising from these elements have to be classified separately. ${ }^{1}$

Financial or Other, Competing Interest: None.

Submission 13-10-2016, Peer Review 17-11-2016,

Acceptance 22-11-2016, Published 08-05-2017.

Corresponding Author:

Sankararaman Balasubramanian,

Associate Professor,

Vinayaka Missions Medical College and Hospital,

Karaikal - 609609.

E-mail:docbdr@gmail.com

DOI: $10.14260 /$ jemds $/ 2017 / 646$

\section{(c) $(1) \ominus$}

- Benign breast disease is the most common cause of breast problems; up to $30 \%$ of women will suffer from a benign breast disorder ${ }^{1}$ requiring treatment at some time in their lives.

- The most important issue is to bear in mind that a patient complaining of breast symptoms can have breast cancer as well as a benign condition. When breast cancer is not treated early, median survival will be around 3 years. ${ }^{1}$

- Both benign and malignant breast disorders can present with a palpable mass; skin dimpling, thickening or erythema; pain; nipple discharge and inversion or distortion or an abnormal screening mammogram with no clinical findings. ${ }^{2}$

- It is very important to collect as much information as possible prior to the definitive surgical treatment as the 
approach to surgery in malignant and benign disease differs. With inadequate surgery, you may worsen the chances of your patient being cured and benefitted by the treatment instituted.

- Studies of benign breast disease can also clarify whether there is a continuum of breast alterations that culminates in breast cancer. However, it remains unclear which of the benign entities are actual precursors and which reflect a background of increased risk involving all breast tissue in a woman, ${ }^{3}$ but some conditions caution that they may pose a risk.

- Breast diseases even in benign status poses considerable anxiety and fear to the suffering woman and to her blood relatives.

- This leads to extensive investigative modalities in benign breast diseases including MRI and wire localisation of the impalpable lesion.

- Benign breast disease is an important risk factor for a later breast cancer, which can develop in either breasts.

- Important questions however include the degree of risk with the common non-proliferative benign entities, family history, etc. influencing. ${ }^{2}$

- The identification of benign breast disease has become more common as the use of mammography and sonomammogram has increased, and thus having accurate risk estimates for women who are diagnosed as benign is imperative. ${ }^{3,4}$

\section{MATERIALS AND METHODS}

A prospective clinical study of 320 patients, among which 4 patients were presented briefly below. The chi-square test was used to analyse the values in the results. The standard deviation, $\mathrm{p}$ value and ' $\mathrm{t}$ ' score were computed and tabulated.

\section{Inclusion Criteria}

1. Bilateral breast disease.

2. Clinically cystic disease of both the breasts with nipple discharge.

3. Sonogram/sonomammogram confirmation of bilateral cystic lesions.

\section{Exclusion Criteria}

1. Unilateral breast disease.

2. Previous history of breast malignancy treated in one breast.

3. Pregnant women.

\section{Methods}

Patients who were attending the OPD in Department of Surgery, VMMCH, Karaikal and also patients with breast lump attending the private clinic in Thanjavur with clinical suspicion of breast lump and proven with ultrasound or sonomammogram are taken in the study. A total of 320 patients were taken and out of which 4 cases which were proven to be malignant were discussed in detail. The chisquare test was used to analyse the values in the results. The standard deviation, $p$ value and ' $t$ ' scores were computed and tabulated.

Patient A- 45 yrs. old perimenopausal woman. She was operated one and a half years back for benign cystic diseaseexcision biopsy for proliferative breast disease.

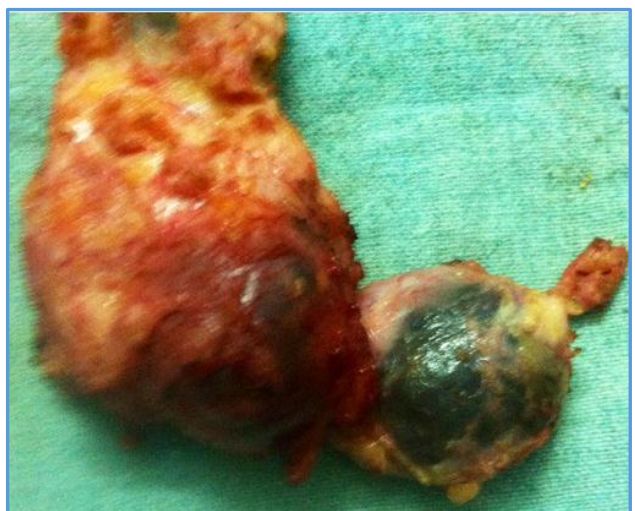

Figure 1. Intra-op Picture of Benign Fibrocystic Lesion

She has a family history of breast carcinoma.

Mammogram showed mass lesion with clustered microcalcification with ill-defined margin.

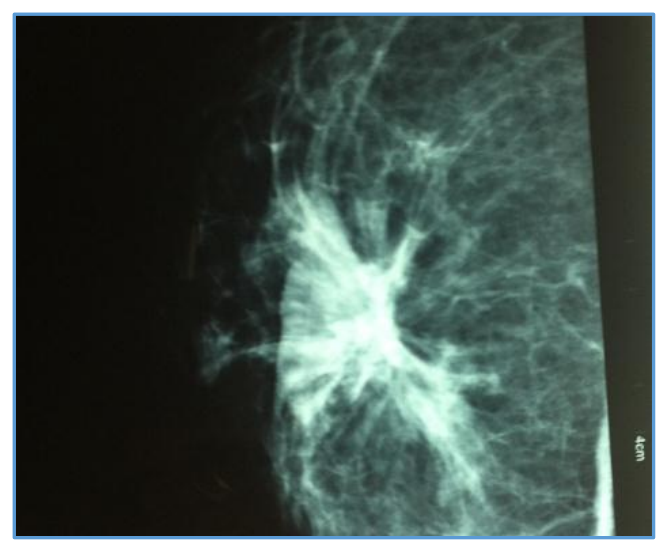

Figure 2. Satellite Mass with Clustered Microcalcification

Stellate mass with Clustered microcalcification.

Tru-cut biopsy showed as infiltrating ductal carcinoma following which MRM was done.

Patient B- 50 years old, post-menopausal, unmarried woman complains of swelling in both the breasts; 2 years back she was conservatively managed for benign fibrocystic disease. She gave a history of increase in size of the swelling.

Tru-cut biopsy- Invasive ductal carcinoma following which MRM was done.

Mammogram- Irregular mass with calcification.

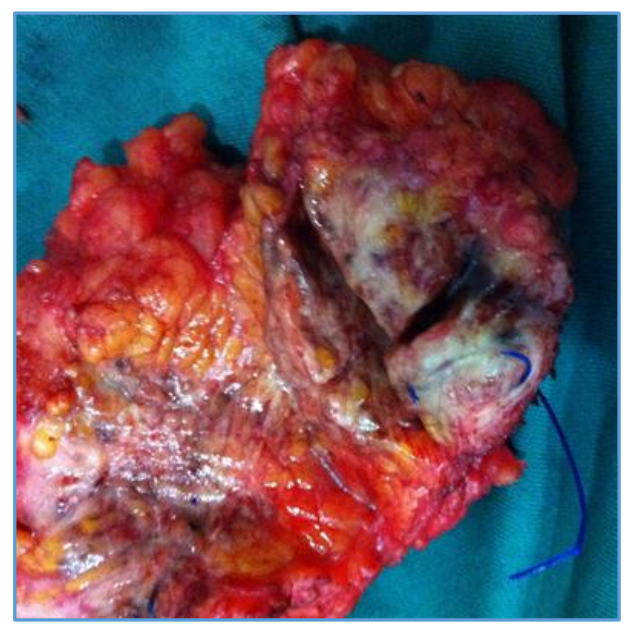

Figure 3. Post-op Pic: Cystic component with Malignancy 
Patient C- 46 years old perimenopausal unmarried woman, complains of swelling in both the breasts. She has a family history of breast CA. History of excision biopsy for sclerosing adenosis with dysplastic changes 1 year back. She has developed a swelling in the same breast.

During followup she was subjected to FNAC after mammogram with suspicious lesion and the result was infiltrating ductal CA. She had a lump on other side of breast, which was found to be benign. Revision MRM done on the left side. Prophylactic risk reduction mastectomy on the other side was done- patient demanded.

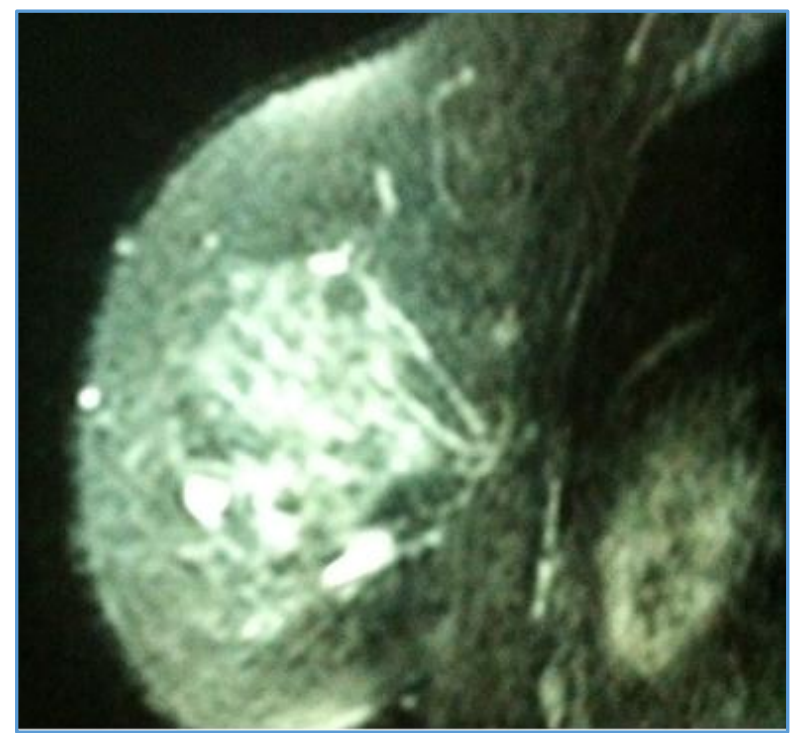

Figure 4. MRI - Showing Gadolinium Enhancement

Patient D- 40 yrs. old unmarried nulliparous woman had swelling in both the breasts for 2 yrs. One year back for benign fibrocystic disease- wide local excision done. On followup, she presented with hard and nodular lesion in same breast.

Tru-cut biopsy was infiltrating ductal carcinoma. During followup patient was advised surgery, but patient opted for surgery elsewhere.

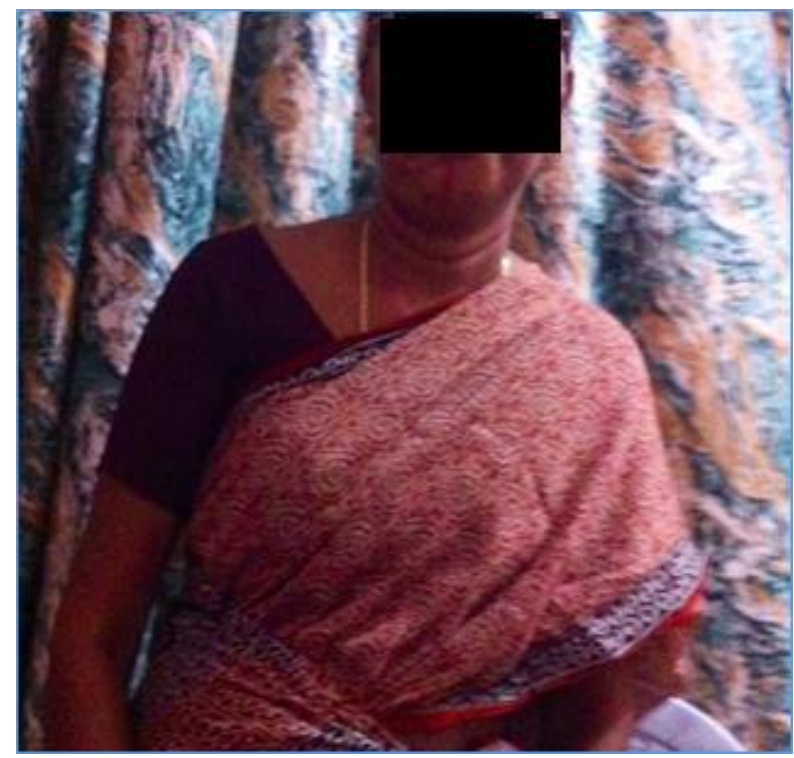

Figure 5. Bilateral Mastectomy

\section{RESULTS}

320 cases of bilateral benign breast disease were studied, out of which 4 cases were found to be malignant during followup. The results were computed using chi-square test and tabulated. The 4 cases were studied briefly and the results were as follows.

\begin{tabular}{|c|c|c|}
\hline Sl. No. & Total Patients & $\mathbf{3 2 0}$ \\
\hline 1. & Benign & 316 \\
\hline 2. & Malignant & 4 \\
\hline \multicolumn{2}{|c|}{ Table 1 } \\
\hline
\end{tabular}

\section{Age Wise Distribution}

\begin{tabular}{|c|c|c|c|}
\hline $\begin{array}{c}\text { Sl. } \\
\text { No. }\end{array}$ & $\begin{array}{c}\text { Age } \\
\text { (Years) }\end{array}$ & $\begin{array}{c}\text { No. of } \\
\text { Patients }\end{array}$ & $\begin{array}{c}\text { No. of Patients- } \\
\text { Proven Malignancy }\end{array}$ \\
\hline 1. & $20-29$ & 54 & NIL \\
\hline 2. & $30-39$ & 56 & NIL \\
\hline 3. & $40-49$ & 72 & 3 \\
\hline 4. & $50-59$ & 70 & 1 \\
\hline 5. & $60-69$ & 68 & NIL \\
\hline \multicolumn{3}{|c|}{ Table 2 } \\
\hline
\end{tabular}

\begin{tabular}{|c|c|c|c|}
\hline \multicolumn{4}{|c|}{ Chi-Square Tests } \\
\hline & Value & $\mathbf{d f}$ & $\begin{array}{c}\text { Asymp. Sig. } \\
\text { (2-Sided) }\end{array}$ \\
\hline Pearson Chi-Square & $7.233^{\mathrm{a}}$ & 4 & .124 \\
\hline Likelihood Ratio & 7.582 & 4 & .108 \\
\hline $\begin{array}{c}\text { Linear-by-Linear } \\
\text { Association }\end{array}$ & .030 & 1 & .863 \\
\hline \multicolumn{4}{|c|}{ Table 3 } \\
\hline
\end{tabular}

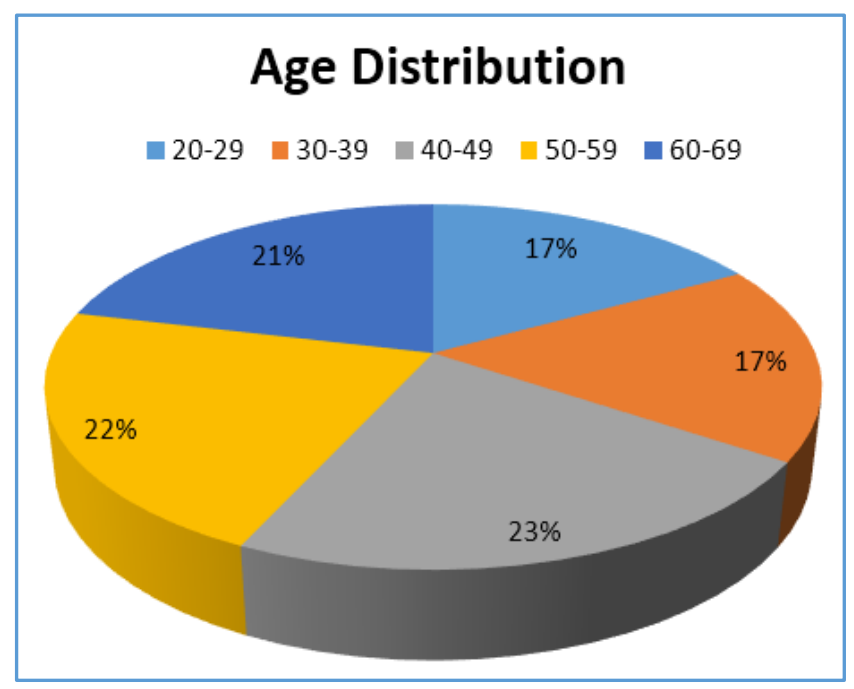

Graph 1

Age wise distribution shows a much increase in the incidence of risk of malignancy, as the age advances. In the age group $40-49$, there are 3 patients out of 72 proved positive for malignancy. Out of 70 patients in the age group 50-59, one patient was tested positive for malignancy. Age wise distribution shows a non-significant ' $p$ ' value of 0.124 . It was calculated using chi-square test. No significant interactions were observed between age and family history. 
- $\quad 316$ cases were found to be benign even after followup for a minimum period of 1 year.

- 4 cases were found to be malignant during followup.

- 3 out of 4 patients had family history of breast malignancy.

- $\quad 3$ of 4 patients had ER +ve.

- $\quad$ PR +ve.

- $\quad$ HER-2/neu +ve.

- 1- Nulliparous unmarried.

\section{Menopausal Status}

\begin{tabular}{|c|c|c|c|c|}
\hline $\begin{array}{c}\text { Sl. } \\
\text { No. }\end{array}$ & Menopausal State & Age & Total & Malignancy \\
\hline 1. & Pre-menopausal & $<40$ years & 110 & Nil \\
\hline 2. & Peri-menopausal & $\begin{array}{c}40-50 \\
\text { years }\end{array}$ & 72 & 3 \\
\hline 3. & Post-menopausal & $>50$ years & 138 & 1 \\
\hline \multicolumn{5}{|c|}{ Table 4 } \\
\hline
\end{tabular}

\begin{tabular}{|c|c|c|c|}
\hline & Value & df & $\begin{array}{c}\text { Asymp. Sig. } \\
\text { (2-Sided) }\end{array}$ \\
\hline Pearson Chi-Square & $6.524^{\mathrm{a}}$ & 2 & .038 \\
\hline Likelihood Ratio & 6.133 & 2 & .047 \\
\hline $\begin{array}{c}\text { Linear-by-Linear } \\
\text { Association }\end{array}$ & .134 & 1 & .714 \\
\hline \multicolumn{3}{|c|}{ Table 5 }
\end{tabular}

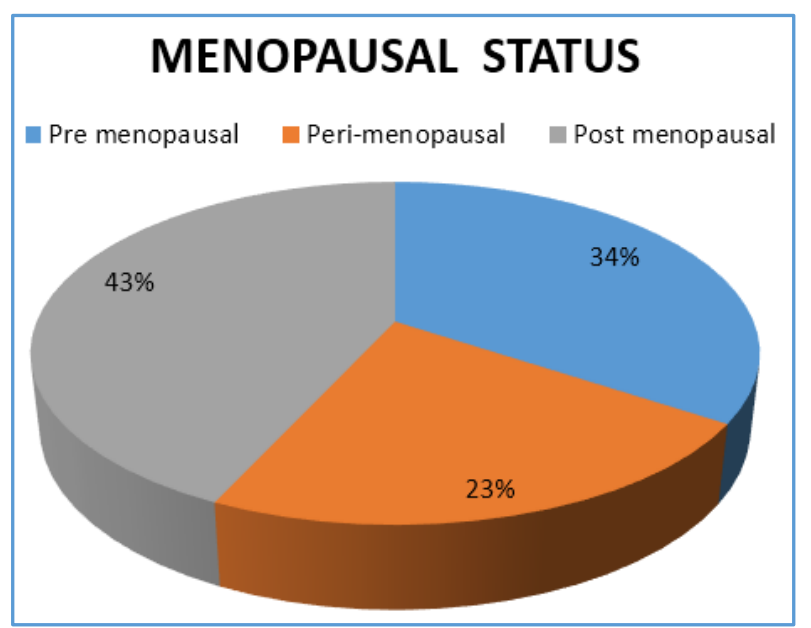

Graph 2

The results in the menopausal status shows a statistically significant value of .036, which was calculated using chi square test. However, there was a significant interaction between the menopausal status, age and the risk of breast cancer.

In the peri-menopausal age group, there is a high incidence of malignancy, i.e. the average menopausal age in the study group being 48 years. There are 3 out of 4 patients with malignancy observed within the age group of $40-50$ years.

\section{Family History of Breast Cancer}

\begin{tabular}{|c|c|c|}
\hline Sl. No. & Family History & No. of Patients \\
\hline 1. & None & 238 \\
\hline 2. & Weak & 84 \\
\hline 3. & Strong & 18 \\
\hline \multicolumn{3}{|c|}{ Table 6 } \\
\hline
\end{tabular}

The family history shows a strong relation in 18 out of 320 patients. But there is a history either weak or strong in a total of 102 patients.

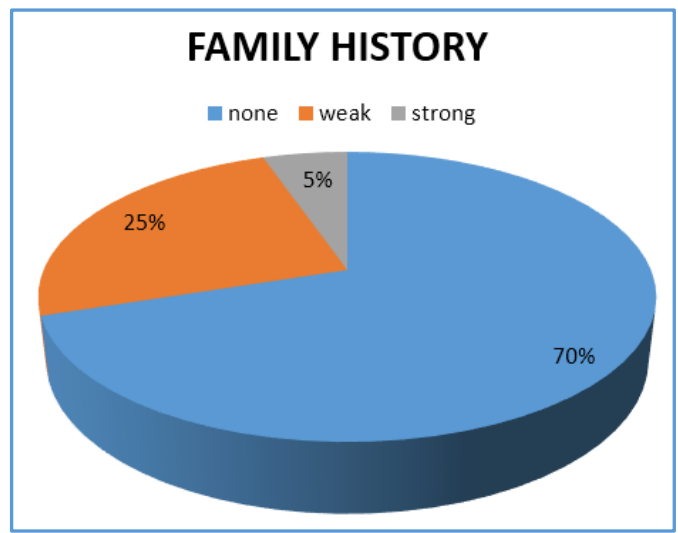

Graph 3

- $\quad$ All four above the age of 40 years.

- High risk patients for developing malignancy.

\section{DISCUSSION}

\section{Risk Factors}

1. Age and Gender- 1 in 233 from ages 30 to 39 years, 1 in 69 from ages 40 to 49,1 in 42 ages 50 to 59, 1 in 29 from ages 60 to 69 and 1 in 8 by age 80 years. ${ }^{5}$

2. Personal History of Breast Cancer.

3. Histologic Risk Factors- LCIS, ADH and ALH (Proliferative lesions with atypia). ${ }^{3,6,7}$

\begin{tabular}{|c|c|}
\hline \multicolumn{2}{|c|}{$\begin{array}{c}\text { Histological Risk Factors for } \\
\text { Development of Breast Cancer }\end{array}$} \\
\hline Histological Diagnosis & Estimates, RR \\
\hline Proliferative Disease & 1.0 \\
\hline Proliferative Disease without Atypia & $1.3-1.9$ \\
\hline Proliferative Disease with Atypia & $3.7-4.2$ \\
\hline Strong Family History & $4-9$ \\
\hline Lobular Carcinoma in Situ & $>7$ \\
\hline Table 7 \\
\hline
\end{tabular}

4. Family History and Genetic Risk Factors- First-degree relatives 2 -fold to 3 -fold excess risk. ${ }^{8}$

5. Genetic factors are estimated to be responsible for $5 \%$ to $10 \%$ of all breast cancer cases, but they may account for $25 \%$ of cases in women younger than 30 years. 9,10

Because the risk for development of breast cancer is high in carriers of a BRCA gene mutation, the use of prophylactic surgery is considered to be the most rational approach. ${ }^{11}$

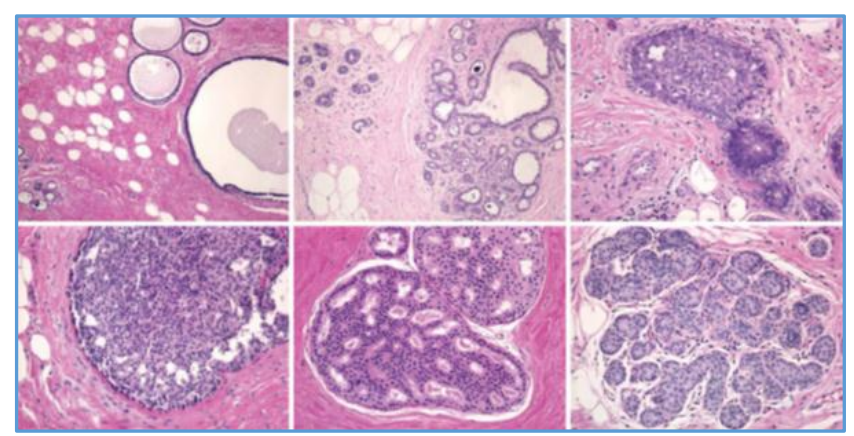

Figure 6. Histopathological Appearance of Benign Breast Disease (Haematoxylin and Eosin) ${ }^{12}$ 
Panel A shows non-proliferative fibrocystic changes: the architecture of the terminal-duct lobular unit is distorted by the formation of microcysts associated with interlobular fibrosis. Panel B shows proliferative hyperplasia without atypia. This is adenosis, a distinctive form of hyperplasia characterised by the proliferation of lobular acini, forming crowded gland-like structures. For comparison, a normal lobule is on the left side. Panel $\mathrm{C}$ also shows proliferative hyperplasia without atypia. This is moderate ductal hyperplasia, which is characterised by a duct that is partially distended by hyperplastic epithelium within the lumen. Panel $\mathrm{D}$ again shows proliferative hyperplasia without atypia, but this is florid ductal hyperplasia: the involved duct is greatly expanded by a crowded, jumbled-appearing epithelial proliferation. Panel E shows atypical ductal hyperplasia: these proliferations are characterised by a combination of architectural complexity with partially formed secondary lumens and mild nuclear hyperchromasia in the epithelial-cell population. Panel F shows atypical lobular hyperplasia: monotonous cells fill the lumens of partially distended acini in this terminal-duct lobule.

6. Reproductive Risk Factors- onset of menarche before 12 years of age, first live childbirth after age 30, nulliparity and menopause after age 55 years. ${ }^{13}$

7. Exogenous Hormone Use- Therapeutic or supplemental oestrogen and progesterone increases the risk of development of breast cancer.

\section{Prophylactic Mastectomy}

Prophylactic mastectomy- reduce the chance of developing breast cancer in high-risk women by $90 \%$.

Several groups have reported on prospective studies in BRCA1 and BRCA2 mutation carriers with prophylactic mastectomy prevent breast cancer. 13,14

More recently, results of Risk-Reducing Mastectomy (RRM) and Risk-Reducing Salpingo-Oophorectomy (RRSO) were reported in BRCA1 and BRCA2 mutation carriers. ${ }^{15}$

\section{CONCLUSION}

- High risk population must be screened routinely.3,7,11

- The risk of malignancy is very high following benign breast disease.

- Unless it is obviously benign, only histology may rule out breast cancer. ${ }^{12}$

- When performing surgery beware when operating on the lesion- include larger or smaller margins according to the findings and do not remove the whole breast tissue.

- Our study shows that histologic features, the age at biopsy and the degree of family history are major determinants of the risk of breast cancer after the diagnosis of benign breast disease.

- Any infection needs close monitoring, care and enough patience for healing. ${ }^{6,17}$

- Understanding the risk associated with benign breast disease is important, because the increasing use of mammography has increased the frequency of breast biopsies, most of which yield benign findings. 18

- In a retrospective study of women undergoing annual mammographic screening, Elmore et al. found that 18.6 percent of women underwent a biopsy after 10 screening mammograms. The use of hormone therapy may also affect the frequency of breast biopsies. Chlebowski et al reporting for the Women's Health Initiative investigators found that relatively short-term therapy with oestrogens plus progestin increased the percentage of women with abnormal mammograms, a major indicator for breast biopsy. 17,19

\section{Summary}

Our study shows that histologic features, the age at biopsy and the degree of family history are major determinants of the risk of breast cancer after the diagnosis of benign breast disease. ${ }^{20}$ We found no increased risk among women with nonproliferative lesions, unless a strong family history was present. No significant interaction between atypia and family history was apparent. The excess risk of cancer in the ipsilateral breast in the first 10 years after the diagnosis of benign breast disease, especially in women with atypia points to the presence of precursors in some women.

\section{REFERENCES}

[1] Connolly JL, Schnitt SJ. Benign breast disease: resolved and unresolved issues. Cancer 1993;71(4):1187-9.

[2] Dupont WD, Page DL. Risk factors for breast cancer in women with proliferative breast disease. N Engl J Med 1985;312(3):146-51.

[3] Fitzgibbons PL, Henson DE, Hutter RV. Benign breast changes and the risk for subsequent breast cancer: an update of the 1985 consensus statement. Cancer Committee of the College of American Pathologists. Arch Pathol Lab Med 1998;122(12):1053-5.

[4] Tomatis L, Aitio A, Day NE, et al. Cancer: causes, occurrence and control. IARC scientific publications No. 100. Lyon: International Agency for Research in Cancer, 1990:69-72.

[5] Hartmann LC, Ghosh K. Benign breast disease: emerging findings in a diverse population. Breast J 2007;13(2):113-4.

[6] Carter CL, Corle DK, Micozzi MS, et al. A prospective study of the development of breast cancer in 16,692 women with benign breast disease. Am J Epidemiol 1988;128(3):467-77.

[7] Worsham MJ, Raju U, Lu M, et al. Risk factors for breast cancer from benign breast disease in a diverse population. Breast Cancer Res Treat 2009;118(1):1-7.

[8] Hartmann LC, Sellers TA, Frost MH, et al. Benign breast disease and the risk of breast cancer. N Engl J Med 2005;353(3):229-37.

[9] Schnitt SJ. Benign breast disease and breast cancer risk: potential role for antiestrogens. Clin Cancer Res 2001;7(12 Suppl):4419s-22s.

[10] London SJ, Connolly JL, Schnitt SJ, et al. A prospective study of benign breast disease and the risk of breast cancer. JAMA 1992;267(7):941-4.

[11] Wang J, Costantino JP, Tan-Chiu E, et al. Lower-category benign breast disease and the risk of invasive breast cancer. J Natl Cancer Inst 2004;96(8):616-20.

[12] Krieger N, Hiatt RA. Risk of breast cancer after benign breast diseases: variation by histologic type, degree of atypia, age at biopsy and length of follow-up. Am J Epidemiol 1992;135(6):619-31. 


\section{Jemds.com}

[13] Schindler AE. Dydrogesterone and other progestins in benign breast disease: an overview. Arch Gynecol Obstet 2011;283(2):369-71.

[14] Kandel R, Li SQ, Ozcelik H, et al. p53 Protein accumulation and mutations in normal and benign breast tissue. Int J Cancer 2000;87(1):73-8.

[15] Kandel R, Zhu XL, Li SQ, et al. Cyclin D1 protein overexpression and gene amplification in benign breast tissue and breast cancer risk. Eur J Cancer Prev 2001;10(1):43-51.

[16] Dupont WD, Parl FF, Hartmann WH, et al. Breast cancer risk associated with proliferative breast disease and atypical hyperplasia. Cancer 1993;71(4):1258-65.

[17] Chlebowski RT, Hendrix SL, Langer RD, et al. Influence of estrogen plus progestin on breast cancer and mammography in healthy postmenopausal women: the Women's Health Initiative Randomized Trial. JAMA 2003;289(24):3243-53.

\section{Original Research Article}

[18] Elmore JG, Barton MB, Moceri VM, et al. Ten-year risk of false positive screening mammograms and clinical breast examinations. N Engl J Med 1998;338(16):108996.

[19] Crawford YG, Gauthier ML, Joubel A, et al. Histologically normal human mammary epithelia with silenced p16 (INK4a) overexpress COX-2, promoting a premalignant program. Cancer Cell 2004;5(3):263-73.

[20] Li JJ, Weroha SJ, Lingle WL, et al. Estrogen mediates aurora- a overexpression, centrosome amplification, chromosomal instability and breast cancer in female ACI rats. Proc Natl Acad Sci USA 2004;101(52):181238. 